\title{
Shift in social order - shift in gender roles? Migration experience and gender roles
}

\author{
Tetiana Havlin \\ University of Siegen, Siegen, Germany
}

Does gender matter in the context of immigration? What significance does it gain through time? Does transition from one gender role to another result in redistribution of family roles? These are the main questions which this paper addresses through scientific discourse and empiric research. In particular the paper deals with the question whether the transition from one gender role to another in the course of immigration triggers the liberalization of gender roles in the families of East-European immigrants (from Ukraine, Russia, Kazakhstan, and Armenia) in Germany. This is investigated through semi-structured biographical interviews with female immigrants to Germany conducted by the author in 2012-2014. The findings illustrate a specific shift of gender roles in the context of migration. On the one hand, willingly or through circumstances, immigrant women are more likely to be involved in the decision-making process, to adapt to a breadwinner role, and to undertake the communication functions with official institutions (often due to better language proficiency). On the other hand, men are more likely to be more engaged in the caregiver roles for offspring, to maintain native language in communication with children (from mother tongue to 'father tongue'), and to fulfill housekeeping duties. These patterns are rather untypical for post-soviet gender roles, with their increasing tendency to the renaissance of traditional gender roles.

The question of whether a shift in gender roles related to migration from one country to another leads towards the greater liberalization of gender roles still remains debatable. But migration experience reinforces the transformation of gender roles which initially are not only distinct but also unequal. Thus, migration can accelerate restructuring of the gender relationship. In turn, a new social order imposes - on immigrants - a demand for greater flexibility of gender roles in the family and for diversity in household strategies.

\section{KEY WORDS}

gender roles; immigration experience; East-European immigrants

CORRESPonding AUthor - Tetiana Havlin, Ph.D., University of Siegen, 257068 Adolf-Reichwein Str., Siegen, Germany, e-mail: havlin@soziologie.uni-siegen.de

AUthors' CONTRIBUtion - A: Study design - B: Data collection - C: Statistical analysis - D: Data interpretation .

E: Manuscript preparation · F: Literature search · G: Funds collection

TO CITE THIS ARTICLE - Havlin, T. (2015). Shift in social order - shift in gender roles? Migration experience and gender

roles. Current Issues in Personality Psychology, 3(3), 185-191.

RECEIVED 06.05.2015 · REVIEWED 13.06.2015 · ACCEPTED 12.07.2015 · PUBLISHED 27.07.2015 


\section{BACKGROUND}

The significance of the gender dimension in the global migration process has changed with time. Initially defined as passive or even deviant and mere followers of their male partners, female contributions were ignored in the international migration (Lutz, 2010). Rapid feminization of migration flows in the middle of the last century required revision of migration with greater consideration towards both genders (Castles \& Miller, 2009; Donato, Gabaccia, Holdaway, Manalansan, \& Pessar, 2006). The latter was also intensified with the development of feminist and gender studies, which made gender an integral part of understanding and explaining migratory processes (Andall, 2003; Anthias, Kontos, \& Morokvasic-Müller, 2013; Buijs, 1996; Dausien, Calloni, \& Friese, 2000; Forbes Martin, 2004; Krummel, 2012; Moreno, 2002; Piper, 2009). Thus, disregard of women in migrant studies was followed by the increase of a research body investigating feminization of migration. As June Rush argues, this was essential in order to gain distance from the notions of "woman as homemaker, circumscribed by domestic routines" which has remained prevalent in different societies (Nash, 1999, p. 3). But at some point, focusing only on women-related issues slowed down the investigation to what extent gender "contextualizes migration processes for all immigrants, men and women" (Hondagneu-Sotelo, 2000, p. 114).

To understand the relation between migration and gender, scholars Susie Jolly and Hazel Reeves offer the following interrelation scheme. On one hand, migration as a multidimensional process is able to either increase inequalities by entrenching traditional roles or bring changes by challenging them. On the other hand, gender aspects of migration indicate who migrates and why, and how the process of decision-making proceeds, i.e. the role of human agency (Jolly $\&$ Reeves, 2005). These mutual influences demonstrate interdependence between migration and gender.

Following this logic of interdependence, the objectives of the present paper are, firstly, to distinguish how gender variables are embedded in migration and how they shape modern migration dynamics, i.e. gender migratory trends. Secondly, attention is focused on the transformation of gender roles which occurs under the impact of migration experience. The latter is analyzed in the case of female East-European immigrants to Germany.

\section{MIGRATION TRENDS FROM THE GENDER PERSPECTIVE: EUROPEAN CONTEXT}

Available data allow us to illustrate some trends in the development of gender variables in the relation to migration. Even though the focus of the article is concentrated on the European context, there are worldwide commonalities which demonstrate interlinks between local and global trends (Eurostat, 2011; United Nations, 2010; United Nations, 2009).

As mentioned above, migration flows of the twentieth century became rather feminized, which led to sex-balanced migration. According to the United $\mathrm{Na}^{-}$ tions estimation, almost half of actual migration stock, i.e. 105 million, is composed of women (United Nations, 2010). Moreover, in some regions of the world, such as Eastern and Northern Europe, and Central and Eastern Asia, women have already outnumbered men among immigrants. In certain countries of the European Union such as Cyprus, Italy, Spain, France and Ireland, female migrants outnumber their male peers, as Figure 1 shows.

Since 1985 there has been a tendency toward evolution of migration drivers. Change of pull factors has been defined by the decrease of family-related and by the increase in importance of employmentrelated migration, which in particular has greater significance in relation to women. Thus, in 1985-1989, among migrants who arrived in the European Union for employment reasons, $41 \%$ were men and $18 \%$ women. In 2005-2008 these percentages were $55 \%$ and $32 \%$ respectively (Eurostat, 2011).

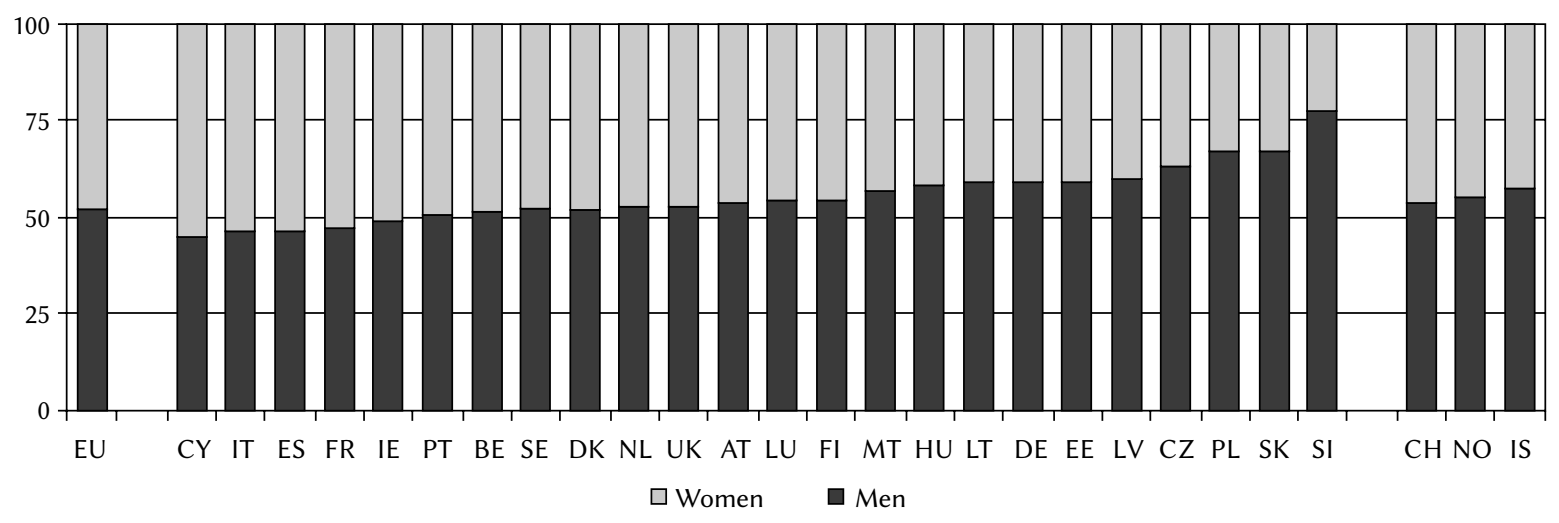

Figure 1. Immigrants by gender, EU-27 and EFTA, 2008 (\%) (Eurostat, 2011, p. 19). 
Tetiana Havlin

Table 1

Activity rate of persons aged 25-54 in the 13 main citizenship groups of third-country nationals in the EU-27 by gender, 2008 (\%) (Eurostat, 2011, p. 84)

\begin{tabular}{cccc}
\hline & Men, $\%$ & Women, $\%$ & Gap (percentage points) \\
\hline National & 92 & 78 & 14 \\
Pakistan & 90 & 17 & 43 \\
Morocco & 89 & 43 & 45 \\
Algeria & 88 & 43 & 43 \\
Turkey & 90 & 47 & 42 \\
Albania & 97 & 55 & 37 \\
India & 94 & 58 & 29 \\
Serbia & 89 & 61 & 23 \\
United States of America & 90 & 68 & 21 \\
Russia & 87 & 66 & 20 \\
Bosnia & 91 & 71 & 19 \\
Brazil & 97 & 78 & 17 \\
Ukraine & 93 & 76 & 15 \\
China & 81 & 66 & 43 \\
\hline
\end{tabular}

In spite of the increase of employment-driven migration, it has not prevented problems related to labor market integration in the destination countries, and female migrants are subjected to these issues to a greater extent than their male peers (Eurostat, 2011). Access to the particular gendered labor niche of the host country, language and cultural obstacles, lack of networks or demanded qualification, and pitfalls of gender stereotypes are a few of those problems. Additionally, the gender roles of the home country and cultural traditions partially explain the issues of female labor market integration and employment rates in the receiving countries. The similarities of the economic activity rates between genders in the home country and the destination country indicate a certain correlation (Eurostat, 2011) (See Table 1).

For instance, according to United Nations data, in 2011 the gap between male and female economic activity rate was $60 \%$ in Pakistan, $49 \%$ in Morocco, $57 \%$ in Algeria, $43 \%$ in Turkey, $52 \%$ in India, $15 \%$ in Russia, and $14 \%$ in Ukraine (United Nations Statistics Division, 2011). Thus, a gender gap in labor force participation among immigrants in the receiving countries is considerably similar to the existing situation in the labor market in the home country.

Another phenomenon, which is not only related to migration but finds larger extension after migration, is overqualification or the gap between high educational level and low- or medium-skilled jobs. Both migrant men and women face this issue in the postmigration period, even though women are affected slightly more by it than men, $38 \%$ and $35 \%$ respectively (Eurostat, 2011).

The gender demarcation of occupational spheres exists beyond the migration context, but what makes it more specific through migration is the fact that migrants are excluded from or restricted in access to jobs in the public sectors as public administration, defense, and education. With different proportions, but both men and women immigrants are involved predominantly in such spheres of employment as manufacturing, wholesale and retail trade, accommodation and food service activities. While construction, transportation and storage are predominated by men, human health, social work as well as paid activities in households are the preserve of female migrants (Eurostat, 2011). This, of course, anchors their positions in particular sectors of the labor market: paid household services, health, child and elderly care for women and construction and logistics for men.

The presented gender patterns illustrate a certain liberalization of the role of women in the migratory context. Women have grown in numbers in the international arena and on the global labor market. They have become a more active part of the world population, and employment has decreased their economic dependency on men. In spite of this, certain disparities and inequalities still do exist in relation to women when viewed through the migration prism: low activity rates among particular ethnic groups, and troubles related to labor market integration and gendered sectors of the economy. 


\section{MIGRATION EXPERIENCE AND TRANSITION OF GENDER ROLES}

As a starting point of the transition in the physical and social spaces, migration influences personality from different angles. On the one hand, these are transformations in terms of self-perception and self-reflection, i.e. identity, ethnic, religious or group affiliations. On the other hand, these are alterations in terms of behavioral practices, i.e. revision of roles and restructuring of household strategies. Once set on the move, human agency is challenged to a greater extent; it requires active strategic actions and personal transformations in order to adjust to the new socio-economic and socio-cultural contexts (Bauman, 2006). The second part of this article aims to answer whether the migration experience reshapes the gender roles in the new surroundings.

\section{SHIFT IN SOCIAL (GENDERED) ORDER}

A major part of migration flows from the Eastern to Western, from the Southern to Northern countries, in other words, from developing to developed societies (United Nations, 2009). The latter are advanced with respect to human rights and political freedoms, in accordance with cultural progress, economic and well-being development indices, and also in terms of gender relations embedded in the particular gender roles (UN Development Programme, 2014). We will pay close attention to the latter phenomenon.

Disparities in gender roles between home and receiving countries which men and women face during migration may lead to clashes (scenario 1), comparison and inclination towards the new gender roles (scenario 2) or preservation of the home country gender traditions (scenario 3).

In the case of the first and second scenarios, the former role division is not taken for granted anymore but falls under the influence of reevaluation within the new contextual perspective. Optionally, it may lead either to the restructuring of family roles or to a separation or even a divorce (Nash, 1999). Men's home authority is questioned, which may be connected to a loss of prestige at home or at work. Male unemployment and connected to that personal disorders intensifies this situation even more.

In other words, scholars Monica Boynd and Elizabeth Grieco define the shift in gender roles within the migratory process as a transition from one type of a gender stratification system to another or 'one system of patriarchy to another' (Boyd \& Grieco, 2003). This transfer can lead to empowerment of migrant women, improvement of their social positions in the receiving society and within their family, as well as liberalization of social positioning for both men and women.

\section{EAST-EUROPEAN IMMIGRANTS TO GERMANY: 'SHIFT IN GENDER ROLES'}

In the case of East-European migrants from the postSoviet region to Germany, we can witness the shift from artificially enforced official USSR top-down feminism with state-encouraged emancipation towards bottom-up and top-down feminist traditions with consecutive emancipation in the German context (Zherebkina et al., 2007; Carstensen \& Groß, 2006).

Describing new tendencies connected to the gender roles in the post-Soviet epoch, Tatiana Zhurzhenko in her work "Old Ideology of a New Family" depicts them in terms of 'patriarchy renaissance'. She argues that this revival was partially stipulated in reaction to the Soviet official egalitarianism (Zhurzhenko, 2004). 'A super-woman strategy' based on 'double shift', paid and unpaid, was exposed to critical revision (Tureckaja, 2001, p. 72).

The findings of the qualitative research "The Bottom-Up Integration of Immigrants from Former Soviet Countries to Germany" (Havlin, 2013), on which this part of the article is based, indicate that there are a few noticeable twists in the restructuring of gender roles which have taken place in the post-migration period. From this standpoint, gender is viewed as a dynamic social construct which shapes behavioral and household strategies, family relationships and roles (Lorber, 1994; Havlin (Sklyaruk), 2005).

Interviewees' profile. Fourteen semi-structured biographical interviews with migrant women from post-Soviet countries (Russia, Ukraine, Kazakhstan, and Armenia) were conducted by the author during the period 2012-2014 in the city of Kaiserslautern, Rhineland-Palatinate, Germany. The age range of the interviewees varies between 22 and 60 years. The migration experience ranges from 5 to over 20 years in some cases. All women have had experience in relationships: eight of them are married (or remarried), seven out of fourteen have had experience with divorce, and three have partners. Six participants have two children, four have one child, and the rest (mostly in their 20 s or early 30 s) are without children. The majority of interviewees with higher education are employed (permanent as well as temporary jobs or in the form of self-employment through entrepreneurship activities), two were completing their studies, one was searching for a job at the time of the interview, and another recognized her status as a housewife with readiness to work, given an opportunity.

Findings. Analyzing the influence of the migration experience on the reshaping of gender roles, it is reasonable to perceive it at two interdependent levels: pre- and post-migration stages.

Apparently, the precondition of female agency was initially demonstrated in the pre-migration period, as some participants pointed out. Already at that 
time they were decision makers or push factors for families to immigrate: It was '92. The coup d'état had happened and... we applied (to leave for Germany). Well, I initiated it... My husband didn't want it, Elena (51); With or without you, but I am leaving for Germa$n y$, Svetlana (39).

The post-migration stage intensifies the tendency of female agency and challenges it even more in the new foreign setting. According to the interviewees, their faster response to language training, to the demands of re-qualification, employment and self-employment, and readiness for flexible or inconvenient working schedules consolidated their active and independent positions inside their families and relationships.

Thus, the capacity to learn German language quicker in comparison to their husbands/partners put some of the participants in the position of a communicator and a negotiator with the official or outside world. ...Only when he has some official affairs does he have to know German. And then WE, or rather my mom, has to do that because he has troubles with German, as Irina (21) describes the situation with her father, who has been in Germany for fourteen years.

There are a few situations which led women to take over the role of a breadwinner in their families: - re-qualification and subsequent employment, as it was in the case of Svetlana through mastering a qualified job as a social worker while her husband remained in a low-skilled occupation as a manual worker. As a result, the difference in earnings between spouses is 600 euro to Svetlana's advantage; - multiple jobs with night and weekend shifts in the case of Olga, employed in the sphere of health and elderly care, earning 1700 euro monthly while her husband's wage is 1300 as a long-distance driver;

- entrepreneurial involvement in services, such as wellness and therapy, party management, catering and entertainment, or sales of cosmetics and household goods works as a tool to fight unemployment and a way towards gaining economic independence from men. Thus, Elena describes her situation when she started a sale business alone, engaging after some time her unemployed husband and making a family business out of it. In general, self-employment practices are especially popular among ethnic minorities and serve as a coping strategy with joblessness and integration into the labor market of the receiving country (Crow, 1989).

Another essential field of migrant women empowerment and their social visibility is their active network engagement. The feature 'women empower women' was described previously by the researcher June Rush in her observation of other migrant groups in the USA (Nash, 1999, p. 8). Through involvement in public social work, e.g. migration integration counseling, ethnic unions, religious communities, or creative activities, such as dancing groups or choirs, they build networks or gain access to already existing ones. This means access to useful information such as job opportunities, to services provided by other immigrants, for instance, health, elderly or child care, catering, entertainment, or simply moral support and encouragement. Men are less present in such networks.

Immigrant men, compliant to changes in the new setting, share roles of care givers for children as, for example, Elena (51) describes her husband's situation: They didn't give him German classes any further. So he was raising Zhenja (daughter). She was learning German with her father. He was helping her at school... Under the circumstances, men take over housekeeping responsibilities, as Svetlana (39) recalls her times of re-qualification in Germany: I was just calming myself down that if he didn't want it, he would never get into that, or as Elena (51) draws attention toward the changing role of her husband at home after his injuries and professional disability: Misha was staying at home, he completely adopted the role of Hausmann (househusband).

In this trend of increasing female agency, it is worth paying attention to how diverse the female perceptions depicted above of the 'twist of gender roles' are. Describing her family situation, Svetlana (49) designates it with the idiom head over heels, i.e. 'upside-down'. With this expression she tried to signify that it does not fall under accepted traditional gender patterns. Instead they are replaced with a more flexible form of interaction based on a double-income household with shared responsibilities in housekeeping and child care. Others, as it is in the case of Elena, employ the strategy 'you are the boss' (a husband), but 'I am the one who is in charge here'. For some East-European women it remains essential to retain and support their husbands' authority and dominance. To some extent, it takes the form of 'show-off dominance'.

In the situation of Karina, after divorcing her Armenian husband, she came to the conclusion that she did not want to be involved in a relationship with any 'Russak' anymore, perceiving them as carriers of the traditional role models. 'Russak', a slang version of the word 'Russian' which applies to men, bears a slightly negative connotation and generalizes men from the former Soviet-countries with a particular type of behavior. Her later relationships with German men only vindicate her beliefs.

Analyzing the relationship between her parents shaped in accordance with male dominance and female subordination, i.e. the basis of a classical role model, Irina (21), who migrated with her family at an early age, criticizes this role pattern and rejects this adoption into her own relationship with a Russian immigrant young man.

The gender role frame allowed us to see how migration experiences influence family structure and 
reshape perception and division of gender roles. Enforcement of female agency through migration undermines traditional division of gender roles und challenges their male partners to respond flexibly to the newly established situation at home and outside. For some women from the sample, the migration experience meant an increase of their social mobility, economic independence, and relative autonomy. Partially, it may be influenced by the fact that almost all participants at the time of the interviews were involved in the labor market or had an intention to be engaged in the near future. Thus, new economic and social settings of the receiving country and efficiency of more flexible gender roles may lead to the balanced re-distribution of power and authority within the families. These may also cause positive transformations in the relationships inside of the families. Of course, these are qualitative changes which have been taking place in the migrant families. In quantitative terms, as we could see from the first part of the article, women are still at a disadvantage in the labor marked and remain as a dependent part.

\section{CONCLUSIONS}

In spite of gender inequalities and disparities preserved within migration processes, female migrants and their issues are becoming more visible in related statistics and research. The emergence among the migrant families of female-based households places migrant women in the positions of a family breadwinner and a decision-maker, and as a bridge between the family and the outside world. It also challenges male migrants to compromise with respect to the restructuring of family and gender roles. This phenomenon can be seen, on the one hand, as gender emancipation and escape 'from patriarchal and abusive social relations' (Billson \& Fluehr-Lobban, 2005, p. 57). On the other hand, it can be viewed as part of a household strategy aimed at survival in the foreign setting.

The question of whether a shift in gender roles related to migration from one country to another leads towards the greater liberalization of gender roles still remains debatable. But migration experience reinforces the transformation of gender roles which are 'not only distinct but are also unequal' (Halford, 1992, pp. 156-157). Thus, migration can accelerate restructuring of the gender relationship, and the new social order imposes on migrants a demand for greater flexibility in gender roles within the family and for diversity in household strategies.

The tendency to greater egalitarianism linked to the post-migration period is also described by Pierrette Hondagneu-Sotelo with the example of undocumented Mexican families in the USA (HondagneuSotelo, 2000). She argues that these families exhibit a more egalitarian approach in the household division of labor or family decision-making process than they demonstrated prior to migration. Thus, the migration experience misbalances to some extent previous sets of gender roles which may not be efficient in the new surroundings anymore, as the findings of the present research showed, and leads to the reshaping of gender discourse.

This paper was presented previously during $10^{\text {th }}$ International Conference "Woman in Culture: Gender, Culture \& Migration" held at University of Gdansk, Poland, in March 2015. The conference was co-funded from Norway Grants in the Polish-Norwegian Research Programme operated by the National Centre for Research and Development.

\section{RefERENCES}

Andall, J. (ed.). (2003). Gender and ethnicity in contemporary Europe. Oxford: Berg. Retrieved from http://www.loc.gov/catdir/enhancements/fy0613/ 2002151688-t.html.

Anthias, F., Kontos, M., \& Morokvasic-Müller, M. (eds.). (2013). Paradoxes of integration: female migrants in Europe. Dordrecht, New York: Springer.

Bauman, Z. (2006). Liquid modernity. Cambridge, UK, Malden, MA: Polity Press; Blackwell. Retrieved from http://neilsquire.pbworks.com/w/file/ fetch/35116162/Bauman-LiquidModernity.pdf.

Billson, J. M., \& Fluehr-Lobban, C. (eds.). (2005). Female well-being: toward a global theory of social change. London, New York: Zed Books.

Boyd, M., \& Grieco, E. (2003). Women and migration: incorporating gender into international migration theory. Retrieved from http://www.migrationinformation.org/Feature/display.cfm?id=106.

Buijs, G. (ed.). (1996). Cross-cultural perspectives on women: Vol. 7. Migrant Women: Crossing Boundaries and Changing Identities (repr.). Oxford: Berg.

Carstensen, T., \& Groß, M. (2006). Feminismen: Strömungen, Widersprüche und Herausforderungen [Feminism: Trends, Contraductions, and Challanges]. In: FAU-MAT (ed.), Gender und Arbeit. Geschlechterverhältnisse im Kapitalismus [Gender and Work: Gender Relationships in Capitalism] (1 $1^{\text {st }}$ ed., pp. 11-32). Lich/Hessen: Verl. Ed. AV [u.a.]. Retrieved from http://www.fh-kiel.de/fileadmin/data/sug/pdf-Dokument/Melanie_Gross/ carstensen_gross_feminismen.pdf.

Castles, S., \& Miller, M. J. (2009). The age of migration: international population movements in the modern world ( $4^{\text {th }}$ ed.). Basingstoke: Palgrave Macmillan. Retrieved from http://www.age-of-migration. com/uk/assets/pdfs/sample.pdf.

Crow, G. (1989). The use of the concept of 'strategy' in recent sociological literature. Sociology, 23, 1-24. 
Dausien, B., Calloni, M., \& Friese, M. (eds.). (2000). Migrationsgeschichten von Frauen: Beiträge und Perspektiven aus der Biographieforschung [Migration reports from women: papers and perspectives from biographical studies]. Bremen: IBL. Bremen: IBL. Retrieved from http://www.gbv.de/dms/hbz/ toc/ht013002393.pdf.

Donato, K. M., Gabaccia, D., Holdaway, J., Manalansan, M., \& Pessar, P. R. (2006). A glass half full? Gender in migration studies. International Migration Review, 40, 3-26.

Eurostat. (2011). Migrants in Europe: A statistical portrait of the first and second generation. Retrieved from http://epp.eurostat.ec.europa.eu/cache/ITY OFFPUB/KS-31-10-539/EN/KS-31-10-539-EN.PDF.

Forbes Martin, S. (2004). Women and migration. Retrieved from http://www.un.org/womenwatch/ daw/meetings/consult/CM-Dec03-WP1.pdf.

Halford, S. (1992). Feminist change in a patriarchal organisation: The experience of women's initiatives in local government and implications for feminist perspectives on state institutions. The Sociological Review, 39, 155-185.

Havlin, T. (2013). The positioning strategies of immigrants: a case study of female immigrants to Germany from former Soviet countries. Sociology Study, 3, 606-615.

Havlin (Sklyaruk), T. (2005). Гендерные роли как символические и знаковые системы социокультурного развития: методологический подход [Gender roles as symbolical systems of socio-cultural development of society: methodological approach]. Sociological Research, 5, 111-119.

Hondagneu-Sotelo, P. (2000). Feminism and migration. The ANNALS of the American Academy of Political and Social Science, 571, 107-120.

Jolly, S., \& Reeves, H. (2005). Gender and migration: overview report. Retrieved from http://www. bridge.ids.ac.uk/reports/CEP-Mig-OR.pdf.

Krummel, S. (2012). Migrant women: stories of empowerment, transformation, exploitation and resistance. Journal of Ethnic and Migration Studies, 38, 1175-1184.

Lorber, J. (1994). Paradoxes of gender. London: Yale University Press.

Lutz, H. (2010). Gender in the migratory process. Journal of Ethnic and Migration Studies, 36, 16471663. DOI: $10.1080 / 1369183 X .2010 .489373$

Moreno, A. B. (2002). Approaches to international migration, immigrant women, and identity. Migraciones Internacionales, 1, 1-28. Retrieved from http://www2.colef.mx/migracionesinternacionales/revistas/MI02/n02-063-092.pdf.

Nash, J. (1999). The transformation of gender roles in migration. Working paper No. 24. Retrieved from http://clrc.soe.ucsc.edu/sites/clrcweb/files/sites/ default/files/WorkingPapers/24_Nash.pdf.

Piper, N. (ed.). (2009). Routledge/UNRISD Research in Gender and Development. New Perspectives on
Gender and Migration: Livelihood, Rights and Entitlements: Routledge. Retrieved from http://www. routledge.com/books/details/9780415874496/.

Tureckaja, G.B. (2001). Деловая активность женщин и семья [Business activities of women and family]. Socis, 2, 67-73.

UN Development Programme. (2014). International human development indicators. Retrieved from http://hdr.undp.org/en/countries.

United Nations. (2010). The World's Women 2010: Trends and Statistics. New York: United Nations publication. Retrieved from http://unstats.un.org/ unsd/demographic/products/ Worldswomen/ WW_fullreport_color.pdf.

United Nations. (2009). Trends in International Migrant Stock: The 2008 Revision. Retrieved from http://www.un.org/esa/population/migration/ UN_MigStock_2008.pdf.

United Nations Statistics Division. (2011). Demographic and Social Statistics. Table 5a - Income and economic activity. Retrieved from http://unstats. un.org/unsd/demographic/ products/socind/.

Zherebkina, I., Gapova, E., Voronina, O., Zdravomyslova, O., Temkina, A., Kon, I. S., \& Bredihina, L. (2007). Политическое воображаемое гендерных исследований в бывшем СССР: взгляды изнутри, снаружи и со стороны [Political imaginary of gender studies in the former USSR: inside and outside perspectives]. Gender Studies, 15, 14-74. Retrieved from http://www.gender.univer. kharkov.ua/gurnal/15/01.pdf.

Zhurzhenko, T. (2004). Старая идеология новой семьи: демографический национализм России и Украины [Old ideology of a new family: demographical nationalism in Russia and Ukraine]. In: S. Ushakin (ed.), Семейные узы: модели для сборки [Family ties: models for assembly]. Moscow: NLO. Retrieved from http://gender-ehu.org/ files/File/Jurjenko.pdf. 